\title{
EHMTI-0028. Occipital neuralgiform pain as multiple sclerosis relapse
}

\author{
M Ozerden*, A Soysal, N Kale, E Coban \\ From 4th European Headache and Migraine Trust International Congress: EHMTIC 2014 \\ Copenhagen, Denmark. 18-21 September 2014
}

Occipital neuralgia $(\mathrm{ON})$ is a rare presentation and might be due to multiple causes including occipital nerve pathologies and limit daily function of patients and have a severe impact on their quality of life (QoL). The clinical cahrecteristics of ON include paroximal painful attacks of electric shock- like sensation, occuring spontaneously or evoked by stimuli in specific tigger areas. Cervical cord demyelination might rareley cause $\mathrm{ON}$. In this case report we would like to report a clinically definite relapsing-remitting multiple sclerosis (MS) patient who experienced occipital neuralgiform pain with a contrast enhancing demyelinating lesion on $\mathrm{C} 2$ cervical cord. We would like to discuss a rare case of occipital neuralgia presenting as an MS relapse. Although patients with multiple sclerosis have an increased incidence of headaches, new onset headaches might be related to a new active lesion and patient sholud be evaluated considering this possibility.

No conflict of interest.

Published: 18 September 2014

doi:10.1186/1129-2377-15-S1-C49

Cite this article as: Ozerden et al.: EHMTI-0028. Occipital neuralgiform pain as multiple sclerosis relapse. The Journal of Headache and Pain 2014 15(Suppl 1):C49.
Department of 3rd Neurology, Bakirkoy Research and Training Hospital for Neurology, Psychiatry and Neurosurgery, Istanbul, Turkey
Submit your manuscript to a SpringerOpen ${ }^{\circ}$ journal and benefit from:

- Convenient online submission

- Rigorous peer review

- Immediate publication on acceptance

- Open access: articles freely available online

- High visibility within the field

- Retaining the copyright to your article

Submit your next manuscript at $>$ springeropen.com

\section{SpringerOpen ${ }^{\circ}$}

(c) 2014 Ozerden et al; licensee Springer. This is an Open Access article distributed under the terms of the Creative Commons Attribution License (http://creativecommons.org/licenses/by/2.0), which permits unrestricted use, distribution, and reproduction in any medium, provided the original work is properly cited. 